\title{
HUBUNGAN BERAT BADAN IBU HAMIL DENGAN KEJADIAN PREEKLAMPSIA DI RUMAH SAKIT UMUM DAERAH dr. ZAINOEL ABIDIN BANDA ACEH
}

\author{
Syahbandi ${ }^{1}$, Eulisa Fajriana ${ }^{2}$, Sirajul Muna ${ }^{3}$ \\ 1,2,3 Kampus STIKes Muhammadiyah Aceh, Indonesia
}

\begin{abstract}
High risks in pregnancy can caused by uncontrolled increasing body weight in pregnancy. It can affect on maternal or fetal. Risk on maternal such as pre eclampsia, gestational diabetes and increase of labor with section secarea. Risks on fetal are risiko macrosomia, obesity in baby, preterm baby or delivery less than 37 weeks of pregnancy. A retrospective study was conducted among 132 pregnant women with pre eclampsia in dr. Zainal Abidin Banda Aceh hospital on August 2021. Data collected using checklist. In the analysis of the data, Chi Square analysis was used. The result found that 97 respondents ( 73,5 \%) are pregnant women with mild pre eclampsia. The body weight of 71 respondents $(53,8 \%)$ increased abnormally on pregnancy. 31 respondents from 71 respondents who had increase their body weight were severe pre eclampsia pregnants women. There were significant correlation between increasing body weight and pre eclampsia in dr. Zainoel Abidin Banda Aceh hospital. Suggestion of the the research is midwife can give counseling about normal limit of body weight gain in the pregnancy dan pre eclampsia in pregnancy.
\end{abstract}

Keywords: body weight gain; pregnancy; preeclampsia 


\section{PENDAHULUAN}

Kehamilan adalah proses yang alamiah setiap wanita, perubahan selama kehamilan normal adalah bersifat fisiologis. Ibu hamil disarankan untuk mengatur berat badan agar tetap berada pada kondisi ideal dan tetap menjaga pola makan dengan gizi cukup dan seimbang. Peningkatan berat badan di trimester pertama memang relatif sedikit, tidak naik atau bahkan berkurang karena muntah-muntah. Peningkatan berat badan yang cukup pesat terjadi di trimester 2 dan 3 , pada periode inilah perlu dilakukan pemantauan ekstra terhadap berat badan. Kenaikan total berat badan selama kehamilan, normalnya berkisar antara 12-15 kg, sedangkan memasuki trimester 2 janin tumbuh pesat dengan pertumbuhan kurang lebih $10 \mathrm{gr}$ per hari/minggu ke 16 sekitar 90 gr, minggu ke 20 sekitar 256 gr, minggu ke 24 sekitar $680 \mathrm{gr}$, minggu ke 27 sekitar 900 gr) (Herawati, 2011)

Kenaikan berat badan pada ibu yang tidak terkontrol/berlebih mengandung banyak risiko kehamilan yang tinggi baik bagi ibu maupun bayi. Risiko pada ibu antara lain adalah pre eklampsia, diabetes gestasional, dan operasi caesar. Sedangkan risiko pada janin antara lain adalah bayi mengalami makrosomia, obesitas pada bayi, bayi lahir prematur atau bayi lahir kurang dari 37 minggu, dan bayi lahir mati. (Mutia \& Iskandar, 2014)
Kenaikan berat badan pada ibu yang tidak terkontrol atau berlebih mengandung banyak resiko kehamilan yang tinggi baik bagi ibu maupun bayi. Resiko pada ibu antara lain adalah preeklampsia, diabetes gestasional dan operasi sesar. Sedangkan risiko pada janin antara lain adalah bayi mengalami makrosomia, obesitas pada bayi, bayi lahir prematur atau bayi lahir kurang dari 37 minggu, dan bayi lahir mati (Mutia \& Iskandar, 2014)

Salah satu resiko penambahan berat badan berlebih bagi ibu hamil adalah preeklampsia. Preeklampsia diperkirakan terjadi pada lima persen kehamilan dan biasanya muncul setelah usia kehamilan 20 minggu. Lebih sering pada kehamilan pertama. Apabila sudah terjadi preeklampsia, lakukan upaya pencegahan untuk tidak menjadi lebih berat. Pengenalan penyakit dan pemeriksaan antenatal memegang peran penting di dalam menghindari kematian dan faktor resiko yang mungkin terjadi. (Manuaba, 2010)

Preeklampsia merupakan masalah kesehatan yang memerlukan perhatian khusus karena preeklampsia adalah penyebab kematian ibu hamil dan perinatal yang tinggi terutama di Negara berkembang. Sampai saat ini preeklampsia dan eklampsia masih merupakan "the disease of theories", karena angka kejadian preeklampsiaeklampsia tetap tinggi dan mengakibatkan angka morbilitas dan 
mortalitas maternal yang tinggi. (Manuaba, 2010)

Menurut (Cunningham et al., 2014) terdapat bererapa faktor resiko yang mempermudah terjadinya preeklampsia seperti usia resiko tinggi kehamilan $(<19$ tahun atau >35 tahun), riwayat hipertensi, kehamilan pertama (primigravida), dan obesitas. Dalam penelitian Dewi tahun 2020 dengan judul hubungan paritas dan usia ibu hamil dengan kejadian preeklampsia disebutkan faktor lain yang dapat mempengaruhi risiko terjadinya preeklampsia di kalangan ibu termasuk diabetes mellitus, kehamilan ganda, riwayat preeklampsia sebelumnya, riwayat preeklampsia dalam keluarga dan penambahan berat badan berlebihan. (Mohanty et al., 2019)

Menurut data Kementerian Kesehatan Republik Indonesia (Kemenkes RI) tahun 2019, jumlah ibu bersalin tercatat sebanyak 5.050 .637 orang dan jumlah kelahiran di Indonesia diperkirakan naik 20\%. Menurut profil kesehatan Indonesia tahun 2018 Angka Kematian Ibu (AKI) di Indonesia mencapai 305 per100.000 kelahiran hidup pada tahun 2015, ini mengalami penurunan dibanding tahun 2012 sebesar 359 per 100.000 kelahiran hidup. Dan target penurunan angka kematian pada tahun 2030 sebesar 131 per 100.000 kelahiran hidup. (Kemenkes RI, 2019)

Kasus kematian ibu yang di sebabkan oleh preeklampsia dan eklamsia mengalami peningkatan menjadi $15 \%$ dari tahun sebelumnya sebesar 10\%. (Dinas Kesehatan Kota Banda Aceh., 2018)

Berdasarkan hasil studi pendahuluan RSUD dr. Zainoel Abidin Banda Aceh, pada periode tahun 2019 jumlah ibu yang mengalami preeklampsia sebanyak 140 orang, dan pada periode tahun 2018 jumlah ibu yang mengalami preeklampsia sebanyak 132 orang. Dari jumlah tersebut sebagian besar terjadi pada ibu yang mengalami kenaikan berat badan lebih dari $10 \mathrm{~kg}$ pada saat ibu hamil dan sedikitnya terjadi pada ibu yang mengalami penurunan berat badan kurang dari $10 \mathrm{~kg}$ pada saat hamil.

Berdasarkan latar belakang yang telah peneliti uraikan diatas, maka penulis tertarik untuk melakukan penelitian tentang "Hubungan kenaikan berat badan ibu hamil dengan kejadian preeklampsia di Rumah Sakit Umum Daerah dr. Zainoel Abidin Banda Aceh tahun 2021".

\section{METODOLOGI PENELITIAN}

Desain yang digunakan dalam penelitian ini adalah menggunakan pendekatan retrospektif. Teknik pengambilan sampel menggunakan metode total populasi dimana sampel di ambil dengan mencatat seluruh responden yang mengalami preeklampsia yang tercatat dibuku register di RSUD dr. Zainoel Abidin Banda Aceh tahun 2020 sebanyak 132 orang. Menggunakan lembar cheklist dengan kriteria penilaian : 
Normal bila kenaikan berat badan ibu hamil trimester $23 \mathrm{~kg}$ dan trimester $36 \mathrm{~kg}$. Tidak normal bila kenaikan berat badan ibu hamil trimester $2<3 \mathrm{~kg}$ dan trimester 3 $>6 \mathrm{~kg}$.

\section{HASIL PENELITIAN DAN BAHASAN}

\section{Analisa Univariat}

Analisa univariat dari penelitian ini dapat dilihat pada tabel distribusi berdasarkan kejadian preeklampsia di RSUD dr Zainoel Abidin Banda Aceh dan tabel distribusi kenaikan berat badan ibu hamil dibawah ini

Tabel.1 Distribusi Frekuensi Berdasarkan Kejadian preeklampsia di RSUD dr. Zainoel Abidin Banda Aceh

\begin{tabular}{clcc}
\hline No & $\begin{array}{c}\text { Kejadian } \\
\text { Preeklampsia }\end{array}$ & $\mathrm{f}$ & $\%$ \\
\hline 1 & Ringan & 97 & $73,5 \%$ \\
\hline 2 & Berat & 35 & $26,5 \%$ \\
\hline & Jumlah & 132 & 100 \\
\hline
\end{tabular}

Berdasarkan tabel.1 menunjukkan bahwa dari 132 responden, dapat dilihat bahwa ibu yang mengalami preeklampsia ringan sebanyak 97 orang (73,5\%).

Tabel.2 Distribusi Frekuensi Berdasarkan Kenaikan berat badan ibu hamil di RSUD dr. Zainoel Abidin Banda Aceh

\begin{tabular}{cccc}
\hline No & $\begin{array}{c}\text { Kenaikan Berat } \\
\text { Badan lbu } \\
\text { Hamil }\end{array}$ & $\mathrm{f}$ & $\%$ \\
\hline 1 & Normal & 61 & $46,2 \%$ \\
\hline 2 & Tidak Normal & 71 & $53,8 \%$ \\
\hline & Jumlah & 132 & 100 \\
\hline
\end{tabular}

Berdasarkan tabel.2 menunjukkan bahwa dari 132 responden, dapat dilihat bahwa ibu yang mengalami kenaikan berat badan tidak normal pada saat hamil sebanyak 71 orang $(53,8 \%)$.

\section{Analisa Bivariat}

Tabel.3 Distribusi frekuensi hubungan Kenaikan berat badan ibu hamil dengan kejadian preeklampsia di RSUD dr. Zainoel Abidin Banda Aceh

\begin{tabular}{|c|c|c|c|c|c|c|c|c|}
\hline \multirow{3}{*}{$\begin{array}{l}\mathrm{N} \\
\mathrm{O}\end{array}$} & \multirow{3}{*}{$\begin{array}{l}\text { Kenaikan } \\
\text { Berat } \\
\text { Badan } \\
\text { Ibu Hamil }\end{array}$} & \multicolumn{6}{|c|}{ Kejadian Preeklampsia } & \multirow{2}{*}{$\begin{array}{c}p- \\
\text { value }\end{array}$} \\
\hline & & \multicolumn{2}{|c|}{ Ringan } & \multicolumn{2}{|c|}{ Berat } & \multirow[b]{2}{*}{$\begin{array}{l}\text { jum } \\
\text { lah }\end{array}$} & \multirow[b]{2}{*}{$\%$} & \\
\hline & & $f$ & $\%$ & $f$ & $\%$ & & & 0,000 \\
\hline 1 & Normal & $\begin{array}{l}5 \\
7\end{array}$ & 93,4 & 4 & 6,6 & 61 & 100 & \\
\hline 2 & $\begin{array}{l}\text { Tidak } \\
\text { Normal }\end{array}$ & $\begin{array}{l}4 \\
0\end{array}$ & 56,3 & 31 & 43,7 & 71 & 100 & \\
\hline & Jumlah & $\begin{array}{l}9 \\
7\end{array}$ & & 35 & & 132 & & \\
\hline
\end{tabular}

Berdasarkan tabel.3 diatas dapat dilihat bahwa dari 71 responden kenaikan berat badan ibu hamil yang tidak normal sebagian besar ibu yang mengalami preeklampsia berat sebanyak 31 orang $(43,7 \%)$

Berdasarkan uji stastistik didapatkan nilai $p$ value 0.000 , sehingga dapat disimpulkan bahwa ada hubungan yang signifikan kenaikan berat badan ibu hamil dengan kejadian pre-eklampsia di RSUD dr. Zainoel Abidin Banda Aceh.

\section{PEMBAHASAN}

Berdasarkan hasil penelitian diatas dapat dilihat bahwa dari 71 responden kenaikan berat badan ibu hamil yang tidak normal sebagian besar ibu 
yang mengalami preeklampsia berat sebanyak 31 orang $(43,7 \%)$.

Berdasarkan uji stastistik didapatkan nilai $\mathrm{P}$ value $=0.001$, sehingga dapat disimpulkan bahwa ada hubungan yang signifikan kenaikan berat badan ibu hamil dengan kejadian preeklampsia di RSUD dr. Zainoel Abidin

Penelitian ini sejalan dengan penelitian (Sri, 2011) bahwa ibu hamil dengan berat badan kurang sebagian besar mengalami preeklampsia berat $(27,6 \%)$, ibu hamil dengan berat badan normal sebagian besar mengalami preeklampsia ringan $(75,0 \%)$, dan ibu hamil dengan berat badan berlebih sebagian besar mengalami preeklampsia berat (32,8\%). Hasil analisis bivariat menggunakan uji chi square diperoleh nilai $p=0,004$ dan $\times 2=10.811$. Nilai $p=$ 0,000 yang lebih kecil dari $=0,05$

Penambahan berat badan yang berlebihan memiliki resiko tiga sampai empat kali Obesitas kelas II dan III empat kali lebih besar untuk menderita preeklampsia dibandingkan wanita hamil dengan berat badan normal. Pada kehamilan volume darah ibu bertambah 25\% pada puncak kehamilan 32 minggu. Hubungan antara resiko preeklampsia, eklampsi, dengan obesitas dapat diketahui karena kelainan metabolik. Kelainan metabolik yang terjadi pada obesitas berhubungan dengan besarnya lapisan lemak. Kegemukan dapat membuat beban jantung terlalu berat, karena terjadi vasokontriksi, sehingga tekanan pada pembuluh darah meningkat akibat tebalnya lemak. (Rumaiyah, 2010) Kenaikan berat badan ibu hamil berdampak buruk bagi kesehatannya karena obesitas pada kehamilan akan menyebabkan hipertensi, hiperkolesterol, hiperglikemia yang dikenal dengan $(3 \mathrm{H})$. Hipertensi pada kehamilan membuat janin meninggal, plasenta terputus, Intra Uterine Grow Retardation (IUGR), Intra Uterine Fetal Dead (IUFD), dan abortus. Gejala hipertensi adalah pusing, sakit kepala hebat, mata kabur, oedem pada tungkai, dan tes laboratorium menunjukan protein yang tinggi dalam urine. Hipertensi ini yang akan menyebabkan preeklampsia pada ibu hamil. (Prawirohardjo, 2012)

Banyak penelitian membuktikan adanya hubungan antara obesitas pada kehamilan dengan kejadian hipertensi dan diduga peningkatan berat badan memainkan peranan penting pada mekanisme timbulnya hipertensi pada orang dengan obesitas. Kejadian hipertensi pada obesitas tersebut belum sepenuhnya dipahami, tetapi pada obesitas didapatkan adanya peningkatan volume plasma dan curah jantung yang akan meningkatkan tekanan darah (Rozikhan., 2015)

Preeklampsia pada saat penelitian juga terjadi pada ibu yang umur $<20$ tahun dan > 35 tahun dengan umur kehamilan rata-rata masih pada trimester II dan paritas yang berbeda. Umur seseorang ibu berkaitan dengan alat-alat 
reproduksi wanita. Umur reproduksi yang sehat dan aman adalah umur 20-35 tahun. Kehamilan diusia $<20$ tahun dan $>$ 35 tahun dapat menyebabkan preeklampsia karena pada kehamilan diusia $<20$ tahun secara biologis belum optimal emosinya cenderung labil, mentalnya belum matang sehingga mudah mengalami kecenderungan yang mengakibatkan kurangnya perhatian terhadap pemenuhan kebutuhan zat-zat gizi selama kehamilannya. sedangkan pada usia $>35$ tahun terkait dengan kemunduran dan penurunan daya tahan tubuh serta berbagai penyakit yang sering menimpa diusia ini.

Kenaikan berat badan pada ibu yang tidak terkontrol / berlebih mengandung banyak risiko kehamilan yang tinggi baik bagi ibu maupun bayi. Risiko pada ibu antara lain adalah preeklampsia, diabetes gestasional, dan operasi caesar. Sedangkan risiko pada janin antara lain adalah bayi mengalami makrosomia, obesitas pada bayi, bayi lahir prematur atau bayi lahir kurang dari 37 minggu, dan bayi lahir mati. (Mutia \& Iskandar, 2014)

Kenaikan berat badan yang berlebih merupakan gejala preeklampsia pada ibu hamil. Kenaikan berat badan yang berlebih menunjukkan adanya penimbunan cairan yang berlebihan dalam jaringan tubuh atau disebut oedema yang merupakan pertanda preeklampsia. Oleh karena itu, ibu hamil hendaknya menjaga berat badannya selama hamil agar mengalami kenaikan secara normal. Cara yang dapat dilakukan oleh ibu adalah dengan berolahraga ringan secara teratur, makan dengan menu gizi seimbang namun tidak berlebih, dan istiharat yang cukup.

Ibu hamil yang memiliki riwayat preeklampsia berisiko untuk mengalami preeklampsia kembali, penderita preeklampsia multigravida, 20\% dari mereka adalah ibu hamil dengan preeklampsia pada kehamilan sebelumnya (Mitayani, 2009)

Sejalan dengan penelitian yang dilakukan oleh (Widyastuti, 2015) dalam penelitian yang ia lakukan pada ibu hamil dengan preeklampsia menemukan beberapa respondennya mengkonsumsi makanan yang mengandung lemak tinggi dan makanan yang asin. Makanan yang tinggi lemak dan asin dapat meningkatkan konsentrasi V L D L (Very-low-density lipoprotein) yaitu sejenis lemak yang melekat pada pro- tein didalam darah. VLDL menyebabkan LDL (kolesterol jahat) dalam darah membesar, akibatnya pembuluh darah menyempit sehingga menyebabkan kerusakan sel endotel. Di mana proses kerusakan endotel menyebabkan vasokonstriksi yang menimbulkan tekanan darah tinggi dan kehilangan cairan serta protein intravaskuler yang menyebabkan terjadinya oedema. (Rumaiyah, 2010)

Seperti yang kita ketahui bahwa saat hamil ibu mengalami perubahanperubahan yaitu perubahan fisik dan 
perubahan psikis. Pada perubahan fisik terlihat jelas bentuk badan ibu yang berubah sedangkan pada perubahan psikis ibu hamil yang pernah memiliki riwayat komplikasi pada kehamilan utamanya memiliki riwayat preeklampsia pada kehamilan sebelumnya memicu timbulnya ketakutan kejadian tersebut dapat terulang kembali pada kehamilan ini sehingga dapat memicu terjadinya kecemasan. Dengan adanya kecemasan tersebut dapat meningkatakan tekanan darah ibu karena tubuh akan merespon kecemasan yang ditandai dengan peningkatan adrenalin ibu, sehingga memicu timbulnya preeklampsia (Rumaiyah, 2010)

Peneliti berasumsi, kenaikan berat badan ibu hamil yang tidak normal diperlukan adanya pompa jantung yang ekstra keras agar sirkulasi darah ibu kejanin terpenuhi. Akibat dari tebalnya lemak dapat terjadi vasokontriksi sehingga aliran darah ibu kejanin menjadi terhambat, dimana terjadi peningkatan tekanan pada pembuluh darah disertai adanya peningkatan curah jantung. Peningkatan curah jantung ini akan menyebabkan hipertensi pada kehamilan yang merupakan tanda dan gejala terjadinya preeklampsia. Oleh karena itu kenaikan berat badan ibu hamil sangat berhubungan dengan kejadian preeklampsia pada ibu hamil.

Preeklampsia dengan dapat di deteksi selama ibu rutin untuk melakukan kunjungan antenatal care sehingga ibu yang mengalami preeklampsia dapat dicegah agar tidak mengalami preeklampsia berat dan terkontrol. Preeklampsia juga dapat dicegah dengan mengkonsumsi makanan antioksidan, contoh bahan pangan yang mengandung jenis antioksidan vitamin $A, C$ dan $E$. Kurangnya asupan vitamin A, C, E serta beta karoten dapat menyebabkan ketidakseimbangan antara radikal bebas dan antioksidan dalam tubuh yang pada wanita hamil dapat meningkatkan risiko terjadinya preeklampsia. (Walsh, 2015)

Teori ini sejalan dengan pendapat Mulyani, dkk, 2015 apabila kekurangan antioksidan dapat menyebabkan preeklampsia Salah satu penyebab yang mampu mengakibatkan kerusakan endotel adalah stress oksidatif. Stress oksidatif terjadi apabila konsentrasi radikal bebas di dalam tubuh melebihi kapasitas antioksidan atau berkurangnya kadar antioksidan di dalam tubuh. Radikal bebas yang merusak lipid dan protein sel, dapat menyebabkan preeklampsia. Radikal bebas dapat diterapi dengan pemberian antioksidan seperti vitamin $A, C, E$, serta beta karoten, superoksida dismutase, antioksidan lipid dan glutation peroksidase serta selenium.(Walsh, 2015)

\section{KESIMPULAN}

Ada hubungan kenaikan berat badan ibu hamil dan kejadian 
preeklampsia di Rumah Sakit Umum

Daerah dr. Zainoel Abidin Banda Aceh.

\section{DAFTAR PUSTAKA}

1. Cunningham, F. G., Leveno, K. J., Bloom, S. L., Spong, C. Y., Dashe, J. S., Hoffman, B. L., Casey, B. M., \& Sheffield, J. S. (2014). Williams Obstetrics. USA: McGraw-Hill Companies Inc.

2. Dinas Kesehatan Kota Banda Aceh. (2018). Profil kesehatan Aceh tahun 2018.

3. Herawati. (2011). Berat badan ideal saat

hamil.

https://www.ayahbunda.co.id/kehamil an-gizi-kesehatan/berat-badan-idealsaat-hamil-

4. Kemenkes RI. (2019). Profil kesehatan Republik Indonesia.

5. Manuaba, I. B. S. (2010). IImu kebidanan, penyakit kandungan dan keluarga berencana (15th ed.). EGC.

6. Mitayani. (2009). Asuhan keperawatan maternitas. Jakarta: Salemba Medika.

7. Mohanty, S., Mohanty, I., Mohanty, A., \& Avilas, D. (2019). Clinico-Social Risk Factors For Pre Eclampsia: A Hospital Based Study. International Journal Of Scientific Research, 4, 5052.

8. Mutia, \& Iskandar. (2014). Berat Badan ideal selama kehamilan. https://bidanku.com/berat-badanideal-selama-kehamilan
9. Prawirohardjo, S. (2012). IImu Kebidanan Sarwono Prawirohardjo. Jakarta:Penerbit Yayasan Bina Pustaka.

10. Rozikhan. (2015). Faktor-faktor risiko terjadinya preeklampsia berat di Rumah Sakit Dr. H. Soewondo Kendal. Universitas Diponegoro. Semarang.

11. Rumaiyah, Z. (2010). Hubungan kejadian preeklampsia berat dengan obesitas pada ibu hamil Di Rumah Sakit Cepu. Universitas Muhammadiyah Surakarta.

12. Sri. (2011). Hubungan Penambahan Berat Badan Dengan Kejadian PreeklampsiaPada Ibu Hamil Di Rsud Prof. Dr. Margono Soekardjo Purwokerto. Akademi Kebidanan YLPP Purwokerto.

13. Walsh, V. L. (2015). Buku ajar kebidanan komunitas. Jakarta: EGC.

14. Widyastuti. (2015). Asuhan Kebidanan Ibu Hamil Patologi Pada Ny. F Umur 29 Tahun G2p1a0 Umur Kehamilan 34 Minggu Dengan Hipertensi Di Rsu Assalam Gemolong Sragen. KTI: Sekolah Tinggi IImu Kesehatan Kusuma Husada Surakarta. 